\title{
Analyzing the Influence of Organizational Culture on New Service Design: Case Studies from Turkey
}

\author{
${ }^{*}$ Hatice Calipinar ${ }^{1}$, A. Gozde Iyicil Gozum ${ }^{2}$ \\ ${ }^{1}$ Hacettepe University, Turkey \\ ${ }^{2}$ Ufuk University, Turkey \\ *chatice@hacettepe.edu.tr
}

\begin{abstract}
The process of economic evolution from agriculture to manufacturing is now turning to the service industry. Studies in recent years show that the service sector comprises the major share of the developed countries in the last few decades. As an expanding sector, it is inevitable that new services will be introduced to the processes of a company. Moreover, new service design is likely to be influenced by the culture of the organization. In this study, the effects of the culture on new service design are examined. In order to analyze the effects, a detailed literature review on new service design was prepared. Two case studies, which mainly exemplify new service design, were analyzed in-depth, screened, and examined in the study. Based on prior research and field studies, a conceptual framework and a regional study, which merit further research, are offered in this paper.
\end{abstract}

Key Words: New service design, Organizational culture, online education, e-MBA, Healthcare services,

\section{Introduction}

As the economy changes from goods to services, including changes in information technology, the service industry is becoming more of an issue. Because services are a combination of people and processes, a new service design or redesigning an existing service can easily be affected by human issues. Thus, in designing new services, decision makers must consider each component of the service. For this reason, a wide variety of decisions is needed in order to reach a conclusion. Decisions must be made with the focus on the correct service and target market. Many studies related with the new service design are available. However, new service design and organizational culture issues are scarcely found in these studies. In the study carried out by Cook et al. (2002), the vast array of human issues involved in the service system design is analyzed. The results of the mentioned study show that human interactions can be transformed directly into the service design. Candi (2007) examines the role of design in the development of technology-based services and reports on case studies on a number of new firms. The findings show that the applications of designs in the related cases are motivated to encounter or exploit the distinguishing characteristics of services, which are intangibility, inseparability, heterogeneity, and perish ability. Tax and Stuart (1997) try to fill a gap in the literature by providing an alternative conceptualization of what constitutes a new service. By using a case study method, three key design dimensions of services, which include processes, participants, and physical facilities, are analyzed. Moreover, they find that firms, which systematically plan for growth, are likely to achieve a greater degree of success and experience reduced complications and failures in the introduction of new services to their existing new systems. Stuart (1998) analyzed the impact of service culture and internal politics on design, introduction success and rejection of new service design proposals. According to the results, an existing service culture can have a significant impact on modifying the new service design proposal by generating successful implementation. Additionally, high customer satisfaction levels were found to be more difficult to achieve. All these papers provide an insight into the theoretical and practical use of services. In this paper, we propose that new service design is related to both the organizational culture and the culture of the country. Three levels of discussion will be done in the study. First, we define the service concept and new service design. Secondly, the organizational culture will be explained. Finally, the interaction of new service design and culture will be analyzed in the study. Additionally, two different case studies will be examined.

\section{Literature Review}

A new service can be defined as a change in the service system, which requires different competencies from the existing operation. New service design (NSD) is planning and organizing the components of a service to add a new service or improve the current service quality. In contrast to its recent position, 
there are several definitions for NSD. The earliest contributions on service design were done by Shostack (1982). According to Shostack (1982), the first step towards rational service design is a system for visualizing this phenomenon, enabling services to be given proper position and weight in the market entity context. He also proposes that the design process can be documented and codified using a service blueprint for mapping the events. Johnson, Menor, Roth, and Chase (2000) explained NSD as an overall process of developing new service offerings. Martin and Horne (1993) have used the term service design to cover the whole process from idea to specification. Service development, service design and service innovation are all about the concept of the service. Edvardson, Gustavson, Johnston, and Sanden (2000) defined the service concept, as a detailed description of the customer needs which need to be satisfied, how they are to be satisfied, what is to be done for the customer, and how this is to be achieved. According to Goldstein, Johston, Duffy, and Rao (2002), the service concept plays a key role in service design and development. The service concept defines the how and what of the service design, and helps mediate between customer needs and an organization's strategic intent. In the study, the service concept was identified as the customer's and provider's expectations of what a service should be and the fulfillment of customer needs (Clark et al. 2000, as cited in Goldstein et al., 2002).

Like new product design, new service design requires methods and tools to control time and other elements in the design process. Design tools include service scenarios and cases. Morelli (2006) proposed three main steps for new service design. These are identifying the actors (people, cultural frames, and technological artifacts), the definition of possible service scenarios, and the representation of the service including physical elements, interactions and links. According to Morelli (2006), service tools aim to produce service blueprinting, which include indications of what happen beyond the line of visibility that separates the front office from the back office. In comparing service systems, competencies can be analyzed along three separate dimensions (Tax \& Stuart 1997). These include:

- The degree to which the new process is fundamentally different from the existing process.

- The degree to which the skills and knowledge of new service participants are different from the existing service.

- The degree to which the physical facilities of the new service are fundamentally different from those required for the existing service.

From a different perspective, Cook et al. (2002) studied service design relating to human issues. They analyzed the human side of design, development and deployment of new service technologies. They defended that understanding the fundamental behavioral science principles underlie human interactions and they could approach service design with the same depth in goods production. They also mentioned service encounters and stated that a service encounter was the interaction process between the servers and served. Furthermore, the main groups were related to service encounters. These were the flow of the service experience, the flow of time, and counterfactual reasoning in judging the encounter performance. The flow of service was used to explain what was happening at the same time. It was used to explain how long the service seemed to take, and the counterfactual reasoning in judging the encounter performance, which reflected what you thought about it later. In the study, human issues were used to understand service design. Actually, a new service design can be grouped into six categories: major innovation, start-up business, and new services for the market presently served, service line extensions, service improvements and style changes.

As seen in Table 1, at least six different service designs can be implemented. Just to give an example for the undefined new services to markets, internet-banking services can be utilized. Before 1990's, the internet was not widely used by people, but after being introduced to it most banks introduced a new service to their portfolios, which we now know as internet banking. Credit cards distributed by the banks can be given as an example for the start-up business stage. Kiosks can be given as an example of new services for the market presently served. Service line extensions are adding new items, new routes, and new courses. Online education is an example of this segment. The changes made to current services are called service improvements. Adding new technology helps to make improvements on services like online bookings and internet banking, just to name a couple of them. Lastly and the most common type of new service design is changing styles. For example, most banks put free telephones for their call-centers and kiosks for internet banking in their branches in order to create a modern image. Technology is commonly used for new service design. The success of technological innovations mostly depends on customer acceptance. Customers may need to also learn new skills such as how to operate an automatic teller machine. In addition, as internal customers, employees are affected by new technology and often 
need retraining (Fitzsimmons \& Fitzsimmons, 2008). In some areas, new service design is completed only with technological support. It decreases the amount of human interaction for services (Table 2).

Table 1: A Critical Evaluation of the New Service Development Process

\begin{tabular}{|c|c|}
\hline \multicolumn{2}{|l|}{ New service } \\
\hline Category & Descriptions \\
\hline Major innovation & $\begin{array}{l}\text { New services for markets yet undefined. These innovations are usually } \\
\text { driven by information and computer based technologies. }\end{array}$ \\
\hline Start-up Business & New services in a market that is already served by existing services. \\
\hline $\begin{array}{l}\text { New services for the } \\
\text { market presently } \\
\text { served }\end{array}$ & $\begin{array}{l}\text { New service offered to existing customers of an organization (although the } \\
\text { service may be available from other companies). }\end{array}$ \\
\hline Service line extensions & $\begin{array}{l}\text { Augmentations of the existing service line such as adding new menu items, } \\
\text { new routes and new courses. }\end{array}$ \\
\hline Service improvements & Changes in features of services that are currently being offered. \\
\hline Style changes & $\begin{array}{l}\text { The most common of all "new services" which are modest forms of visible } \\
\text { changes that have an impact on customer perceptions, emotions and } \\
\text { attitudes. No change to the service. Fundamentally, only its appearances. }\end{array}$ \\
\hline
\end{tabular}

Source: Johnson, Menor, Roth \& Chase, A critical Evaluation of the New Service Development Process as cited in J.A. Fitzsimmons and M.J. Fitzsimmons (Eds). New Service Development, Thousand Oaks, Calif, Sage Publications, 2000, p.4.

Table 2: Evolution of Services

\begin{tabular}{llll}
\hline $\begin{array}{l}\text { Service } \\
\text { Industry }\end{array}$ & Human Contact & Machine Assisted & Internet Facilitated \\
\hline Banking & Teller & ATM & Online banking \\
Airlines & Ticket agent & Check-in kiosk & Print boarding pass \\
Restaurants & Wait Person & Vending machine & Online order / delivery \\
Movie Theatre & Ticket sale & Kiosk ticketing & Pay-for-view \\
Book Store & Information clerk & Stock availability terminal & Online shopping \\
Education & Teacher & Computer tutorial & Distance learning
\end{tabular}

Source: Fitzsimmon (2003). Is the future of services self-service? Managing Service Quality, 13, 443-444.

Technology changes the nature of work. Not only do employees but also the customers should be trained about new technology in order to get accustomed to the system. Organizational culture is defined as a set of beliefs, values and assumptions that are shared by members of an organization (Schein, 1985). Gregory, Harris, Armenakis, and Shook (2009) aimed to address the direct and indirect impact of organizational culture on effectiveness. They also studied the service sector, especially hospitals. A positive relationship was found between group culture and patient satisfaction in the study. Moreover, balanced cultures achieved higher levels of patient satisfaction when compared with unbalanced cultures in the study. The innovation culture of an organization is generally linked with innovation outcomes. It is also mentioned that the development of technology-based culture is needed to create a competitive advantage in technology intensive industries (Claver et al., 1998). New technology can be enhanced and implemented with the help of an innovative culture within the organization, which involves mostly risk taking and responsibility. Organizational culture researchers argue that isolating organizational culture content is useful in understanding organizational action (Cameron \& Quinn, 1999). Thus, the research questions of the study are;

- Research Question 1: Is organizational culture types related to new service design?

- Research Question 2: Is organizational culture types related to the frequency of new service design? 
As illustrated in Table 1 organizational culture types are clan, adhocracy, hierarchy, and market. The horizontal axis describes the relative organizational emphasis on internal maintenance to external positioning. The vertical axis describes the continuum from organic to mechanistic processes (Lund, 2003). Previous studies claim that organizations which have adhocracy as the dominant culture type have higher frequencies of both product and service innovation than other culture types. However, it should be mentioned that adhocracy culture is ideal for new service design, but is not the only culture appropriate for innovation. Prior studies about organizational theory suggest that culture has an influence on the nature of innovation. Moreover, according to some academics, organizational culture affects the number of innovations that can be implemented in a given period of time (e.g. Bronikowski, 1990; Peters, 1990; Schoonhoven \& Jelinek, 1990 as cited in Stuart; 1998).

Table 3: A model of Organizational Culture Types

\begin{tabular}{|c|c|}
\hline \multicolumn{2}{|c|}{ Organic Processes: (Flexibility, Spontaneity) } \\
\hline \multirow[b]{5}{*}{$\begin{array}{l}\text { Internal Process Model } \\
\text { (Smoothing activities, integration) }\end{array}$} & Type: Adhocracy \\
\hline & Dominant Attributes: Entrepreneurship, \\
\hline & $\begin{array}{l}\text { Bonding: Entrepreneurship, flexibility, } \\
\text { risk }\end{array}$ \\
\hline & $\begin{array}{l}\text { Strategic Emphases: Toward innovation, } \\
\text { growth, new resources. }\end{array}$ \\
\hline & $\begin{array}{l}\text { External Positioning: } \\
\text { (Competition, differentiation) }\end{array}$ \\
\hline Type: Hierarchy & Type: Market \\
\hline $\begin{array}{l}\text { Dominant Attributes: Order, rules and } \\
\text { regulations, uniformity }\end{array}$ & $\begin{array}{l}\text { Dominant Attributes: Competitiveness, } \\
\text { goal achievement }\end{array}$ \\
\hline Bonding: Rules, policies and procedures & $\begin{array}{l}\text { Bonding: Goal Orientation, production, } \\
\text { competition }\end{array}$ \\
\hline $\begin{array}{l}\text { Strategic Emphases: Toward stability, } \\
\text { predictability, smooth operations }\end{array}$ & $\begin{array}{l}\text { Strategic Emphases: Toward competitive } \\
\text { advantage and market superiority }\end{array}$ \\
\hline Mechanistic Process & trol, Order, Stability \\
\hline
\end{tabular}

Source: A model of organizational culture types adopted by Lund (2003), "Organizational culture and job satisfaction", Journal of Business and Industrial Marketing, 18, 219-236.

The Relationship between Culture and the New Service Design Process: Designing a new service is a creative process. It begins with defining the service concept and strategy to provide a service with specific features that will make a difference from its competitors. According to Kemp and Dwyer (2001), existence of a strong culture can be a powerful enabling force in strategy formulation. The positive effects of increased employee identification and commitment highlight the importance of linking culture and strategy to achieve a higher level of organizational performance. Kemp and Dwyer explained how cultural influences on behavior within an organization come about and their impact on the organization. They also emphasize that organization culture has an important influence on strategies and their success. Swan and Comb (1976), and Schneider (1973; 1980) support the relationship between culture and the service process and believe that there is strong relationship between the service process and service quality. From the perspective of these studies, relationships between the service culture and new service design seem reasonable. Norman (1991) states that environmental services and new core services should be applied carefully so that existing cultures and possible threats to them due to change should not be avoided. Moreover, Norman (1991) also points out that radical innovation of a service process is a pervasive process, which makes it a difficult task. Thus, Norman believes that designing a new service should be consistent with the existing service. Tax and Stuart (1997) created a framework for cultural influences. They suggested that the new service design process could be characterized as a multistage examination of the proposed processes, physical facilities and personnel, as well as the customer attitudes and benefits offered. National and organizational culture was also analysed with a different perspective. 
According to the related studies; organizational culture had more influence on new service design than a national culture (Naor, Linderma, \& Schroeder; 2010). There is a possibility about organizations which have a developmental culture may have a positive influence on new services. It is also known that different types of cultures have different outcomes. Organizations, which especially have an innovative culture, have a comparatively higher level of innovation and new service design. Mostly failures arouse from organizational culture and internal resistance to change. Many services fail in the implementation stage because of cultural influences. The cultural dimension may, in fact, be the service equivalent of the tension in new product innovation within goods industries between market pull and technology push (Noori, 1990; as cited in Stuart, 1998). Organizational innovation research shows that the presence of a relationship between organizational culture and organizational structure influence new service decisions. New service design is a kind of innovation for organizations. The organizational effectiveness and its innovativeness are, thus, assumed to be influenced by the organisational culture (Russell, 1988). In some cases, services are rejected, the reason being that they lack management support, demand, marketing failure and financial constraints. More often, the reason for these kinds of failures depends on the organizational culture and internal resistance to change. The failure of the services is also very common in the implementation stage only because of cultural influences.

\section{Methodology}

The research task and the variables that flow from this literature show that there is a strong correlation between organization culture and new service design. This paper examines the cultural influence on new service design by using a case study approach. Various service organizations were considered and assessed for inclusion as case studies, like a restaurant, coffee shop, dry cleaner and an insurance firm. University A (the original name of the university is kept confidential) was selected because of its adaptation period to the new service. Secondly, University B (the original name of the university is kept confidential) was selected for the study because of the cultural changes in itself.

Case Studies: Experimental and observation techniques are not always applicable for social sciences. In order to analyze the effects of culture on service design it is better to observe case studies. Two case studies of new service design to existing service systems were conducted in the study. The cases were selected based on several criteria. The most important selection criterion was "service organizations". Adding a new service to the existing ones was also a criterion for selection. Because the study was a regional one, the service organizations were selected within Turkey. Information was gathered by interviews. A semi-structured interview technique was used. In the first case, personal interviews were conducted with senior managers, academics, and front office staff who were most closely associated with the new service design and introduction. In the second case, the interview method was applied to department managers, doctors, specialists and front office staff. The names of the organizations are kept confidential due to the privacy of the participants.

Case A- Private University: Nowadays, the higher education environment is experiencing significant changes, and the focus is moving to competitiveness and customer care. Only in Turkey, more than twenty universities have an Electronic Master of Business Administration program. The most popular ones are; Ahmet Yesevi University, Anadolu University, Atılım University, Bahçeşehir University, Beykent University, Gazi University, Orta Doğu Teknik University (METU), Sakarya University, Maltepe University, Fatih University, and Bilgi University. Tuition and other fees differ from one university to another but it is well known that universities profit from on-line programs. A well-known university in Turkey decided to maintain revenue growth in order to supply better services for the university. The university offers both undergraduate, graduate and $\mathrm{PhD}$ degrees. Current graduate programs offered by the social sciences institute of the university are; Master of Business Administration, International Relations, Finance, European Union, Economics, Tourism Management, English Language and Literature, Interpreting and Translation, Translation Sciences, Public Law, Hospital Management, Political Science and Public Administration, Banking and Local Administrations. There are two different types of graduate programs. They include both thesis or without thesis options. Current graduate programs are offered as daytime or evening courses. All graduate lectures are of three-hour duration. Requirements for applying to graduate programs are; letter of recommendations, transcript, the results of a foreign language exam, ALES that includes mathematical and Turkish language question results. Since its establishment in 1997, the university has been expanding by introducing new programs. In addition to these, the demand for graduate programs is increasing each year. In addition, different demands are arising due to the changing 
conjuncture. Market research held by the university's social sciences institute showed that there was a substantial potential for a new e-MBA program.

E-MBA enables students to study online from anywhere in the world in conjunction with a full work schedule. With no need to make frequent trips to Ankara or spend long periods away from home, the course is completed over one and a half years, broken up into three semesters, without forcing students to take a break in their career. With the motivation of customer demand and competition in the market, the university decided to open an online MBA program. The results of the market research showed that service indicated significant market demand and student intention to purchase it. The new service had been carefully designed and structured with adequate capacity provision for staffing and support funding. Additionally a retrospective study of the last two new services was done by the university. The program was discussed in previous years but the request for starting it was rejected by the Turkish Council of Higher Education (YOK) as being unsuitable with the current system for both the infrastructure and technology. However, with the help of the increase on demand and developments in technology infrastructure, YOK changed its decision regarding online education. Without any advertising activity, the first-degree program admitted eighteen new students. In the second year, the number of the students was thirty-two and in the third year, the number was twenty-two. Although it has been only three years since starting this new service, the total number of students is now seventy-two. According to the institute of social sciences of the university, the demand will increase because of the advantages of on-line education. The program content includes eleven courses and a project, which is almost equivalent to other graduate programs. Tutors indicated that they would use the notes that they use in the current lectures. The organizational type of the university is "Adhocracy" (Table 3). Because the university is open to innovation, it has creativity, adaptability, flexibility and risk taking attributes which makes it technology oriented. Because of the technology used, a different kind of culture apart from the traditional education culture is dominant in the organization whereby a need arises. A classical organization structure is not suitable for an online education system. Moreover, an organizational chart for on-line education differs from the classical organizational chart. The organizational chart for the on-line education in the university is shown below:

Figure 1: Organizational Chart of Case A

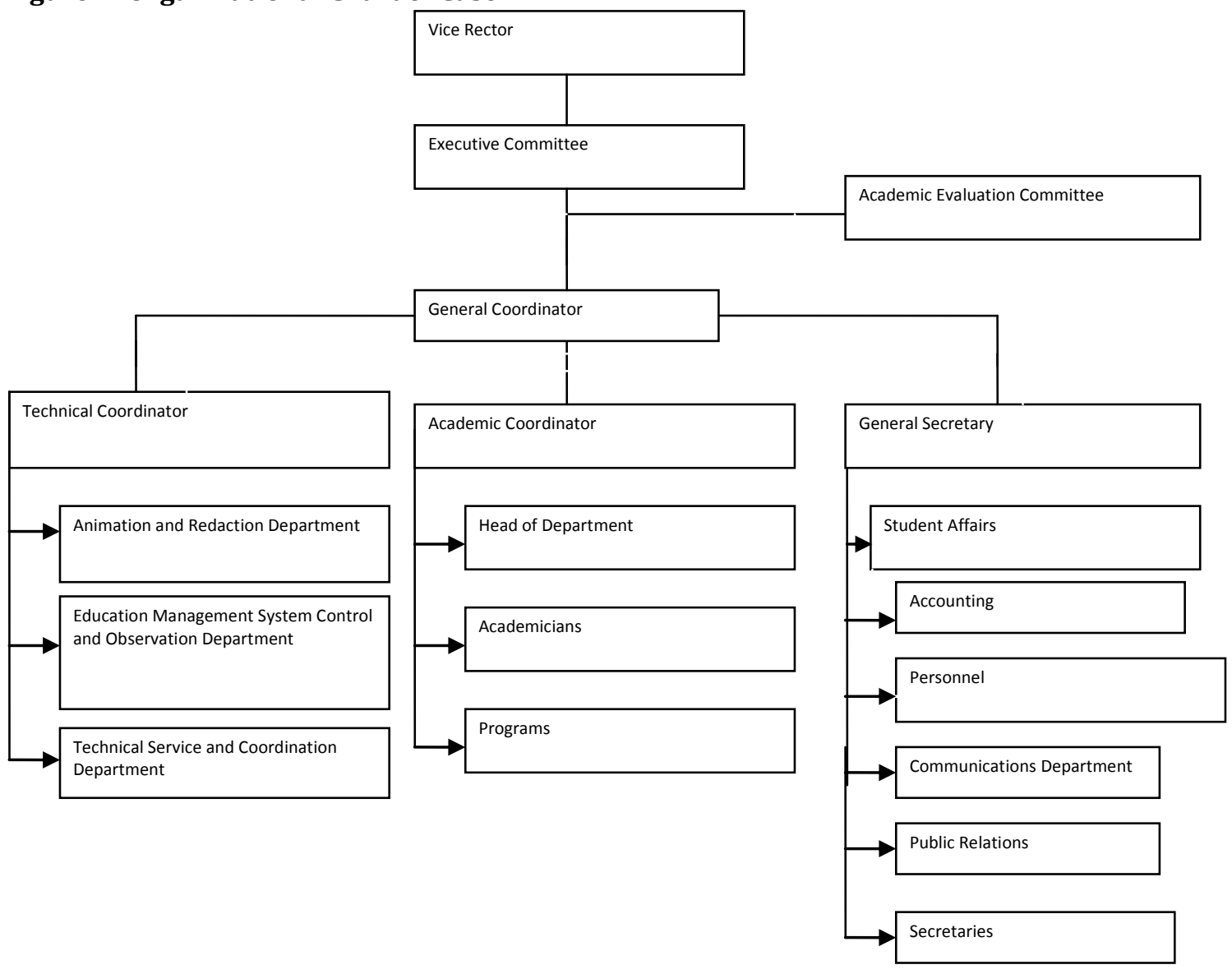


As seen in the chart, there is a technical coordinator; however; there is no need for one within classical education systems. A technical coordinator has an important role in online education because they are responsible for not only the lecture notes but also the books transferred onto an electronic base. Furthermore, midterms are done over the internet while only finals are completed face-to-face. Because it is a newly used service and innovations are configured by information and computer based technologies, it is on the "major innovation" category in the Table 1. The university expects demands in order to increase their capacity in the future. Besides the increasing demand, the university has experienced many advantages of the new service. These include:

- Minimizing the costs on time and place

- Flexibility of online learning. Most of those students were adults who have many other commitments at the same time like a full-time job, family, and school.

- Students who have disabilities submitted to on-line courses. There are more opportunities for interaction with instructors with online courses. Online learning is perceived to be more relaxed while interacting with the instructors more closely than the students normally do in traditional classroom settings.

- Development of virtual team building skills. Collaboration with peers in an online learning environment was beneficial for them to develop virtual team building skills. Virtual team building skills are also important skill for global business environment.

Today distance education is an important function of the educational institutions. However, some of the universities in Turkey have a conservative culture and they resist an online education system. On the other hand, the organizations, which have an innovative culture, are open to new ideas including new service design.

Case B- Private Hospital and Nutrition \& Dietetics: Previously owned by a foundation but currently a private hospital decided to add a new department within its establishment. First established as a (charitable) foundation hospital in 1972, traffic, work, sports and other injuries were aimed to be treated in the hospital. In 1999, the hospital was turned into a university, which now also belongs to the Turkish Council of Higher Education (YOK). The main aim of the university is to prevent, protect, and treat accidents, disasters, physical and mental problems for both individuals and the public. The hospital has a one hundred and twenty-bed capacity. It also has an outpatients unit. The organization's former culture could best be described as "conservative". Adding new services, renewing the current services or removing the unnecessary services have not been considered before because of the hospital's culture. However, after having turned it into a university, the culture of the hospital naturally changed as innovative and progressive. The management of the university decided to add new services in order to strike a blow in its market. After market research, university management decided to add a nutrition and dietetics department in itself. The reasons for adding this department are listed below:

- Potential market share

- Position of the competitors

- Increase in demand because of an increasing number of patients

- Increasing demand because of the era of image.

Before adding the new department, a comprehensive market research was done. The results showed that almost every hospital in Turkey has a nutrition and dietetics department. In addition, the front desk of the hospital pointed out that there were a significant number of requests for the introduction of nutrition and dietetics. The university hospital, which has an innovative management, also has an innovative culture, and motivation towards expanding by adding new services. Today, the nutrition and dietetics department receives an average of twelve patients. The hospital management is very pleased with the outcomes of the department. It has achieved its goals over a ten-year period.

\section{Analysis of the Two Case Studies and Key Findings}

The summary of the case studies, including the impact of culture on the design and implementation of EMBA and Nutrition and Dietetics departments, can be seen in Table 4. In case A, the reason for adding a new service to the main body is shown in table 4 . These reasons are due to an increasing demand and a competitive market. Stakeholders, more specifically, service participants, were new customers, just because that the service was new. Current employees were preferred for the new service. However, technical employees were recruited especially for the new service. It was seen that the impact of the culture was effective on new service design. As in the first case, in case B, the reason for new service design was demand and the profitable market segment and the competitors. Similarly, since it was a new 
department, service participants were all new customers. New personnel were needed for the new department. Finally, it was seen that the cultural impact on service design was effective.

\begin{tabular}{lll} 
Table 4: Case Summary Matrix & & \\
\hline Change in Design Element & $\begin{array}{l}\text { Case A } \\
\text { University \& } \text { e-MBA }\end{array}$ & $\begin{array}{l}\text { Case B } \\
\text { Private Hospital and } \\
\text { Nutrition \& Dietetics }\end{array}$ \\
\hline Reason & $\begin{array}{l}\text { Increasing Demand } \\
\text { Position of the Competitors }\end{array}$ & $\begin{array}{l}\text { Increasing Demand } \\
\text { Position of the Competitors }\end{array}$ \\
Service Facilities & $\begin{array}{l}\text { Compatible with Organizational } \\
\text { Culture }\end{array}$ & $\begin{array}{l}\text { Compatible with Organizational } \\
\text { Culture }\end{array}$ \\
Service Participants & New Customers & New Customers \\
$\begin{array}{l}\text { Personnel } \\
\text { Culture Impact on Service } \\
\text { Design } \\
\text { Information system }\end{array}$ & Existing and New & New \\
\hline
\end{tabular}

New service design and its adaptation to the organizational culture are illustrated in Figure 2. In the conceptual model, the existing service has a shape, which is influenced by the organizational culture. The new service enters the organizational culture boundaries. The result would be either acceptance of the new service prior to adaption to the culture or rejection of the new service. Figure 2 also helps to explain potentially high failure rates for new services and the conditions to be accepted by the organization.

Figure 2: New Service Design and the Influence of the Culture

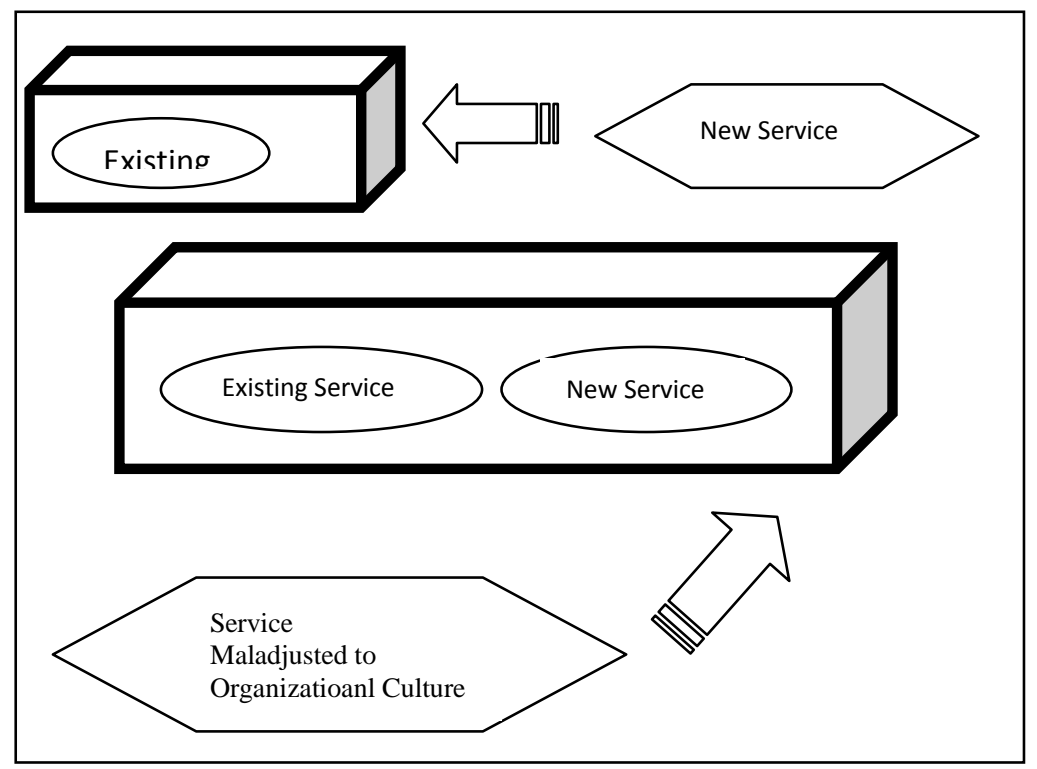

This figure briefly explains the case studies in the study. If new service design does not fit the organizational culture, it is impossible for the new service design to be accepted or to carry on. In the first case, it is seen that universities with a conservative culture did not accept to have an online education program. However, the university, which had an innovative culture, accepted the new service. It is important to mention that both the organizational culture and the concept of the new service design should be suitable to each other; otherwise, the failure of new service design would be inevitable. The influence of the organizational culture on the new service design is remarkable. If the new service design fits or is oriented to organizational culture it is accepted, otherwise it is rejected. It is the same in the second case where it is seen that a university with an innovative culture preferred to have a new department, nutrition and dietetics. Managers of the hospital did not accept a department like nutrition and dietetics because of their organizational culture. However, after becoming a university, the 
organizational culture switched from a conservative culture to an innovative culture and a new service design was accepted.

Discussion and Implications of the Case Studies: The aim of this article was to study new service design within the boundaries of organizational culture literature. This study also investigates the interplay of culture and new service design. Studying the service concept helped us to begin understanding how service providers view services - as a sum of components (processes, facilities, tasks, etc.) or as a singular outcome that is sought from the service process (Goldstein, Johston, Duffy, \& Rao, 2002). Herein it is important to mention that service design cannot be considered without the organizational culture. Admittedly, with increasing globalization, companies are being called to serve customers with divergent needs and expectations shaped by different cultural backgrounds and values (Wong, 2002). In this study, the conceptual framework and the case studies reflect new service design in a cultural context. Culture can be broadly defined as a set of collective programming, whose system of values and norms guide's people's beliefs and behaviors (Hofstede, 1980). Alvesson (2002) states that the social word is seen not as objective, tangible, and measurable but as constructed by people and reproduced by the networks of symbols and meanings that people share and make shared action possible. Schein (1985) has proposed that one of the functions of organizational culture is the adaptation to its external environment. When the demand from the potential customers is combined with the appropriate organizational culture, a new service design decision arose in both the cases mentioned above. In our model, it is emphasized that existing service appear in the related cultural structure. In addition, the new service occurs within the same structure. The acceptance of a new service depends on the possibility of adapting the cultural frame. Otherwise, as seen in the Figure 2, new service will not be accepted. As in the second case, the university's nutrition and dietetics program involved a major cultural shift and adaptation of a new organizational culture. Although at first, the new service design was rejected only because of the conservative culture of the organization, later it was positively considered and accepted by the new organizational culture. As a result, the nutrition and dietetics program was financially successful. It must be admitted that this success belongs to the organizational culture of the university. To sum up, it was seen in the study that the new service design and implementation process were influenced by the organizational culture.

\section{Conclusion}

The main aim of a business is to grow with numbers. Adding new services is a way to grow. However, adding a new service increases the business cost, like research and development, new personnel, new materials and new processes. Especially in innovative organizational cultures, managers are more open to innovation and new service design. These kinds of cultures are generally risk takers, open to innovations and struggles with difficulties. The employees are also the supporter of the innovative decisions. In conservative cultures, members are generally against innovation or new service design. A detailed explanation of the influence on new service design was shown in the case studies. New service design and its process, which is frequently bound by an organizational culture, were analyzed. It was seen that the organizational culture affects new service design decisions. It can be said that there is an interaction between an organization's culture and the introduction of a new service. Further research is needed to advance the knowledge in this area. A longitudinal study, which comprises a long period, would be more useful for shedding light on new service design issues. Moreover, expanded case studies including electronic (online) PhD programs and online undergraduate programs would be useful.

\section{References}

Alvesson, M. (2002). Understanding Organizational Culture, Sage, London.

Bronikowski, K. (1990). Speeding new products to market. Journal of Business Strategy, 3, 34-7.

Cameron, K. S. \& Quinn, R. E. (1999). Diagnosing and changing organizational culture: Based on the competing values framework, Addison-Wesley.

Candi, M. (2007). The role of design in the development of technology-based services. Design Studies, 28, 559-583.

Clark, G., Johnston, R. \& Shulver, M. (2000). Exploiting the service concept for service design and development, In: Fitzsimmons, J., Fitzsimmons, M. (Eds.), New Service Design, Sage, Thousand Oaks, CA, 71-91. 
Claver, E., Llopis, D. G. \& Molina, H. (1998). Organizational culture for innovation and new technological behavior. Journal of High Technology Management Research, 9, 55-68.

Cook, L. S., Bowen D. E., Chase R. B., Dasu, S., Steward, D. M. \& David, A. T. (2002). Human issues in service design. Journal of Operations Management, 20, 159-174.

Edvardsson, B., Gustavsson, A., Johnson, M. D. \& Sanden, B. (2000). New service development and innovation in the new economy, Student literature, Lund, Sweden.

Fitzsimmon, J. A. \& Fitzsimmon, M. J. (2000). New Service Development, Sage Publications, Thousand Oak, CA.

Fitzsimmon, J. A. (2003). Is the future of services self-service? Managing Service Quality, 13, 443-444.

Fitzsimmons, J. A. \& Fitzsimmons, M. J. (2008). Service Management - Operations, Strategy, Information Technology, 6. Edition, McGraw-Hill International Edition.

Goldstein, S. M., Johnston, R., Duffy, J. \& Rao, J. (2002). The service concept: The missing link in service design research. Journal of Operations Management, 20, 121-134.

Gregory, B. T., Harris, S. G., Armenakis, A. A. \& Shook, C. L. (2009). Organizational culture and effectiveness: A study of values, attitudes and organizational outcomes. Journal of Business Research, 62, 673-679.

Hofstede, G. H. (1980). Culture's consequences: international differences in work related values. Sage, Beverly Hills CA.

Johnson, S. P., Menor, L. J., Roth, A. V. \& Chase, R. B. (2000). A critical evaluation of the new service development process. In: Fitzsimmons, J., Fitzsimmons, M. (Eds.), New Service Development, Sage, Thoasand Oaks, CA, 1-32.

Kemp, S. \& Dwyer, L. (2001). An examination of organizational culture - the Regent Hotel, Sydney. Hospitality Management, 20, 77-93.

Lund, D. B. (2003). Organizational culture and job satisfaction. Journal of Business and Industrial Marketing, 18, 219-236.

Martin, C. R. \& Horne, D. A. (1993). Service innovations: successful versus unsuccessful firms. International Journal of Service Industry Management, 4, 49-65.

Morelli, N. (2006). Developing new PPS, methodologies and operational tools. Journal of Cleaner Production, 14, 1495-1501.

Naor, M., Linderman, K. \& Schroeder, R. (2010). The globalization of operations in Eastern and Western countries: Unpacking the relationship between national and organizational culture and its impact on manufacturing performance. Journal of Operations Management, 28, 194-205.

Noori, H. (1990). Managing the Dynamics of New Technology: Issues in Manufacturing Management. Prentice Hall Inc. New Jersey.

Norman, R. (1991). Service management. John Wiley, New York.

Peters, T. (1990). Time-obsessed competition. Management Review, 79, 16-20.

Russel, R. D. (1988). How organisational culture can help to institutionalize the spirit of innovation in entrepreneurial ventures. Journal of Organizational Change Management, 2, 7-15.

Schein, E. H. (1985). Organizational culture and leadership. Josey- Bass San Francisco

Schneider, B. (1980). The service organization: climate is crucial. Organizational Dynamic, 9, 52-65.

Schneider, B. (1973). The perception of organizational climate: the customer's view. Journal of Applied Psychology, 57, 248-56.

Schoonhoven, C. B. \& Jelinek, M. (1990). Dynamic tension in innovative, high technology firms. Managing rapid technology change through organization structure. : In von Glinow, M.A., \& Mohrman, S.A. (Eds). Developing new services. American Marketing Associaiton, Chicago, IL, p.27-43.

Shostack, G. L. (1982). How to design a service. European Journal of Marketing, 16, 49-63.

Stuart, F. I. (1998). The influence of organizational culture and internal politics on new service design and introduction. International Journal of Service Industry Management, 9, 469-485.

Swan, J. E. \& Comb, L. J. (1976). Product performance and consumer satisfaction. Journal of Marketing, 40, 17-30.

Tax, S. \& Stuart, F. I. (1997). Designing and implementing new services: the challenges of integrating service systems. Journal of Retailing, 73, 105-134.

Wong, N. Y. (2004). The role of culture in the perception of service recovery. Journal of Business Research, $57,957-963$. 